\title{
Effects of microwave and ultrasound on the extraction of pectin and its chemical characterisation of banana (Musa sapientum $\mathrm{L}$.) peels
}

\author{
1,*Phaiphan, A., ${ }^{1}$ Churat, S., ${ }^{1}$ Doungta, T., ${ }^{1}$ Wichalin, P., ${ }^{1}$ Khanchai, W. and ${ }^{2}$ Penjumras, P. \\ ${ }^{1}$ Program in Food Technology, Faculty of Agriculture, Ubon Ratchathani Rajabhat University, Ubon \\ Ratchathani Province, 34000, Thailand \\ ${ }^{2}$ Department of Food Technology, Maejo University-Phrae Campus, Maesai, Rongkwang, Phrae Province, \\ 54140, Thailand
}

\section{Article history:}

Received: 24 May 2020

Received in revised form: 30

June 2020

Accepted: 16 July 2020

Available Online: 20 August 2020

\section{Keywords:}

Banana peel,

Extraction,

Microwave,

Pectin,

Ultrasound

DOI:

https://doi.org/10.26656/fr.2017.4(6).248

\begin{abstract}
Pectin is a polysaccharide that is widely used as a food additive in food industries. Banana peels that are discarded by vendors after processing bananas for food products contain a high level of pectin. The pectin can be extracted from the plant cell walls whereas the conventional method for extraction would normally take some time to get a high yield. This research was conducted to explore the effects of microwave-assisted extraction (MAE) and ultrasound-assisted extraction (UAE) on the extraction of pectin and its chemical characteristics found in banana peels. For MAE, the effects of microwave power and extraction time on the yield and quality of extracted pectin was studied. It was found that the pectin yield and chemical characteristics increased with the increase of microwave power and extraction time. The percentage yield ranged from $20.93 \%$ to $22.91 \%$ for microwave power of $300 \mathrm{~W}$ for 5-15 mins. The moisture, ash, degree of esterification, methoxyl, and galacturonic content of extracted pectin by MAE had $8.98 \%, 5.40 \%$, $75.50 \%, 12.00 \%$, and $57.80 \%$, respectively. For UAE, the effects of temperature and sonication time on the pectin yield and quality of the extracted pectin were also studied. The pectin yields ranged from $1.81 \%$ to $3.49 \%$ and the moisture, ash, degree of esterification, methoxyl, and galacturonic content of extracted pectin by UAE had $8.00 \%$, $3.39 \%, 88.83 \%, 14.50 \%$, and $90.07 \%$, respectively. Although the use of MAE promoted a high pectin yield it had a lower purity level when compared to UAE. Besides, the chemical characteristics of the extracted pectin by UAE is more comparable with commercial citrus pectin than the pectin extracted by MAE.
\end{abstract}

\section{Introduction}

At present, many countries have been concerned about the food waste problem. Food waste refers to the discarding or alternative (non-food) use of food that is safe and nutritious for human consumption. The large amounts of organic waste are produced by food waste. Unsuitably treated organic waste causes greenhouse gas emissions because it releases a bulk of methane (FAO, 2019).

Banana is one of the world's largest fruit crop mainly originating from South East Asia but can be found in tropical countries around the world. The world banana production including plantain production for 2017/2018 was 153.1 million tons. The five top countries that produce bananas are India, China, Philippines, Colombia, and Indonesia, respectively (FAOSTAT,
2018). Banana peels are usually discarded by vendors after processing bananas for food products. A majority are used for animal feed and fertilisers. The burden of banana peel waste is continuing to increase and challenging for by-product waste management. In banana producing countries, waste processing of banana peels may have some economic advantages not to mention a decrease in environmental pollution. One of the options of processing banana peels could be used in pectin production due to its various use as a thickener, stabiliser, and gelling agents in food products such as jams and jellies, fruit juice, yogurt, and confectionery (Kratchanova et al., 2004; Happi Emaga, Robert, Ronkart et al., 2008). Besides, other use of pectin can be found in cosmetic and pharmaceutical products (Rolin, 1993).

For pectin production, extraction is an important 
process. The most generally used method of extracting pectin is by strong acid concentration but this method is corrosive, adverse to the environment, has a high cost for treating acidic waste, and maybe a potential threat to health (Rolin, 1993; Voragen et al., 1995; Lucia et al., 2013). Some previous studies have been reported on the extraction of pectin from banana peels and depicted that banana peels could be used as a source of pectin (Khamsucharit et al., 2018; Phaiphan, 2019)

Oliveira et al. (2016) determined the effects of pectin extraction from banana peels with citric acid, the pectin was successfully extracted under different variables such as extraction time, temperature, and $\mathrm{pH}$. Microwaveassisted extraction with a weak organic acid is effective in pectin (yield) extraction and pectin properties (Phaiphan, 2019). The process variables such as salting out time, $\mathrm{pH}$, extraction temperature and time may have an effect on pectin extraction from banana peels (Qiu et al., 2010). Castillo-Israel et al. (2015) have shown that higher yields of pectin can be extracted from Saba banana [Musa saba (Musa acuminate x Musa balbisiana)] peels in the unripe stage with hydrochloric acid and citric acid. The extraction $\mathrm{pH}$ was the important process variable on the extracted pectin yield and their chemical compositions (degree of esterification, galacturonic acid content and total sugars) from banana peel (Happi Emaga, Ronkart, Robert et al., 2008). Among the different varieties of banana peels, the peels that showed the most extracted pectin was from Musa sapientum cv. Kluai Nam Wa which had the highest anhydrouronic acid content $(66.67 \%)$ and could be used as food additive pectin as alternative pectin from fruit peel source (Khamsucharit et al., 2018).

Therefore, the purpose of this work was to obtain pectin from banana (Musa sapientum L. cv. Kluai Nam Wa) peel waste by using microwave-assisted and ultrasound-assisted extraction, and to perform the chemical characterisation of the extracted pectin in order to measure their potential for use as a polysaccharide in food products.

\section{Materials and methods}

\subsection{Chemical reagents}

Standard D-galacturonic acid and Carbazole were purchased from Sigma-Aldrich (St. Louis, Mo, USA). Other reagents, such as phenolphthalein solution indicator, acetone, ethanol 95\%, sodium hydroxide, sulfuric acid and hydrochloric acid, were of analytical grade.

\subsection{Material and sample preparation}

Banana peel (Musa sapientum L. cv. Kluai Nam Wa) wastes were gathered from vendors in Ubon Ratchathani province. They were washed, cut into small pieces (about $1.5 \mathrm{~cm} \times 5 \mathrm{~cm}$ ) and boiled in 95\% ethanol-based solution as reported by Tangwongchai et al. (2006) with slight modifications. Briefly, the banana peel sample was treated with $95 \%$ of ethanol (a ratio of 1:1 fresh sample weight to solvent) at $80^{\circ} \mathrm{C}$ for 10 mins, which resulted in inactivation of endogenous enzymes. This was then followed by washing the sample three times using distilled water. Thereafter, the sample was dried at $65^{\circ} \mathrm{C}$ and ground into fine powder (the moisture content of the sample was $3.92 \pm 0.06 \%$ ). Then, the sample was passed through an 80-mesh pore size sieve and kept in an amber glass bottle at $-18 \pm 1^{\circ} \mathrm{C}$ until subsequent extraction.

\subsection{Pectin extraction using microwave-assisted (MAE) and ultrasound-assisted extraction (UAE)}

\subsubsection{Pectin extraction using MAE method}

MAE of banana peels was carried out based on the method of Li et al. (2012) with slight modifications. A $10 \mathrm{~g}$ sample was added by $0.05 \mathrm{M}$ of hydrochloric acid in a beaker (1:12 dried fruit peel powder to hydrochloric acid, W/V). For MAE extraction, the mixture was extracted by microwave with three powers of 100, 200, and $300 \mathrm{~W}$ for three extraction times $(5,10$, and 15 mins). After that, the sample was centrifuged (4500 rpm for 30 mins) and the supernatant was precipitated by $95 \%$ of ethanol (1:1 the supernatant to ethanol, V/V). The mixture was incubated for $15 \mathrm{hrs}$ at room temperature. Thereafter, the precipitated pectin was filtered using a filter, which was followed by washing three times with $95 \%$ of ethanol and $50 \%$ of acetone to get rid of sugars, such as the monosaccharides and disaccharides (Minkov et al., 1996). Finally, the wet pectin extract was dried in a hot air oven at $60^{\circ} \mathrm{C}$ until its weight remained constant and ground into powder. The percentage yield of pectin was calculated as follows:

$$
\begin{aligned}
& \text { Pectin yield }(\%)=\frac{\text { Dried extracted pectin }(\mathrm{g})}{\text { Dried powder of banana peel }(\mathrm{g})} \times 100 \\
& \text { 2.3.2 Pectin extraction using UAE method }
\end{aligned}
$$

\subsubsection{Pectin extraction using UAE method}

UAE of banana peels was carried out based on the method of Li et al. (2012) with slight modifications. A $10 \mathrm{~g}$ sample was added by $0.05 \mathrm{M}$ of hydrochloric acid in a beaker (1: 12 dried fruit peel powder to hydrochloric acid, W/V). For UAE, the extraction process was carried using the ultrasonic bath system (Branson, model5510, USA), which had a max. input power of $185 \mathrm{~W}$ and frequency of $40 \mathrm{kHz}$, the mixture was treated with three varying temperatures of 30,40 , and $50^{\circ} \mathrm{C}$ for three sonication times $(5,10$, and 15 mins). After that, the sample was centrifuged (4500 rpm for $30 \mathrm{mins}$ ) and the supernatant was precipitated by $95 \%$ of ethanol (1:1 the 
supernatant to ethanol, V/V). The mixture was incubated for $15 \mathrm{hrs}$ at room temperature. Thereafter, the precipitated pectin was filtered using a filter, which was followed by washing three times with $95 \%$ of ethanol and $50 \%$ of acetone. Finally, the wet pectin extract was dried in a hot air oven at $60^{\circ} \mathrm{C}$ until its weight remained constant and ground into powder and the percentage yield of pectin was calculated.

\subsection{Determination of degree of esterification (DE) and methoxyl content}

The DE of pectin sample from banana peel was conducted by the titrimetric method as reported by Bochek et al. (2001). Briefly, the dried pectin $0.3 \mathrm{~g}$ was soaked with $2 \mathrm{~mL}$ of ethanol in a flask and dissolved in $100 \mathrm{~mL}$ of distilled water. Thereafter, five drops of phenolphthalein indicator were added, and the mixture was titrated with $0.5 \mathrm{M}$ of sodium hydroxide solution (the initial titer, $\mathrm{V}_{1}$ ). After that, the mixture was added with $10 \mathrm{~mL}$ of $0.5 \mathrm{M}$ sodium hydroxide and kept for 15 $\min$. Then, $10 \mathrm{~mL}$ of $0.5 \mathrm{M}$ hydrochloric acid was added and followed by the phenolphthalein indicator. The mixture was titrated again with $0.5 \mathrm{M}$ of sodium hydroxide (the final titer, $\mathrm{V}_{2}$ ) until a light pink colour appeared (endpoint). The DE value of the sample was calculated using the formula below, and the methoxyl content was calculated using DE value.

$$
\mathrm{DE}(\%)=\frac{\text { Sodium hydroxide }(\mathrm{V} 2)}{\text { Sodium hydroxide }(\mathrm{V} 1) \pm \text { Sodium hydroxide }(\mathrm{V} 2)} \times 100
$$

\subsection{Determination of galacturonic acid (GalA)}

The determination of total GalA content was carried out according to the method reported by Dedduang (2010). Briefly, the dried pectin $0.1 \mathrm{~g}$ dissolved with 100 $\mathrm{mL}$ of $0.05 \mathrm{M}$ sodium hydroxide and was stirred for 30 mins. Then, $10 \mathrm{~mL}$ of the mixture was taken and adjusted to $100 \mathrm{~mL}$ with distilled water. After that, $2 \mathrm{~mL}$ of diluted pectin solution was transferred to a flask and was added with $1 \mathrm{~mL}$ of $0.1 \%$ Carbazole, followed by adding $12 \mathrm{~mL}$ of sulfuric acid and then stirred for 25 mins. The sample was measured at $525 \mathrm{~nm}$ by a spectrophotometer. The GalA content was determined by comparing it against a standard curve obtained from standard D-GalA concentration at $10-80 \mu \mathrm{g} / \mathrm{mL}(\mathrm{Y}=$ $\left.0.0027 \mathrm{x}+0.0567, R^{2}=0.9969\right)$.

\subsection{Chemical composition of dried pectin}

Ash and moisture content of the extracted pectin were carried out using AOAC methods (AOAC, 2000). The colour $\left(\mathrm{L}^{*} \mathrm{a}^{*} \mathrm{~b}^{*}\right)$ of extracted pectin was determined by a colorimeter (Hunter Lab, colour Flex, VIRG, USA). The $\mathrm{L}^{*}$ value represented as lightness $(0=$ black and $100=$ white), $\mathrm{a}^{*}$ value expressed as greenness or redness $(-\mathrm{a}=$ greenness and $+\mathrm{a}=$ redness $)$, and $\mathrm{b}^{*}$ value expressed as blueness or yellowness $(-b=$ blueness and $+b=$ yellowness).

\subsection{Statistical analysis}

All the measurements obtained values were conducted in triplicates. The experiment for each extraction was carried out in $3 \times 3$ factorial design, in a completely randomised design. The data were analysed using analysis of variance (ANOVA) and Tukey's test for mean comparisons by Minitab software (Version 16.1.1.0) and presented as mean value \pm standard deviation. The confidence level of $p$-value less than 0.05 was statistically significant.

\section{Results and discussion}

\subsection{Pectin extraction by using MAE}

\subsubsection{Effect of microwave power and extraction time on yield and chemical characteristics of pectin}

The results showed that microwave power, extraction time of microwave heating and the interaction between microwave power and heating time had significantly $(p<0.05)$ affected all the responses and all data are presented in Table 1. The pectin yield values increased with the increase of microwave power and extraction period, and the increased yield was sharply found at microwave power of $300 \mathrm{~W}$. The microwave power of $300 \mathrm{~W}$ and the extraction time of $10 \mathrm{mins}$ had the highest yield at $22.91 \%$. When the extraction time increased to 15 mins at the same microwave power $(300$ W) there was no significant difference in the extraction yield (Table 1).

Hypothetically, microwave power causes the cell wall matrix to loosen and also break down the parenchyma cells, thereby increasing the skin tissues and exposing them to microwave power. This can lead to increased efficiency of the extraction between the sample material and extracting solvent. Thus, the penetration of the extracting solvent will be increased and leads to the increase in the pectin yield of extraction (Kratchanova et al., 2004).

Other studies have reported that the total pectin yield depends on the extraction conditions (Happi Emaga, Ronkart, Robert et al., 2008). The extraction yield in this study was $22.91 \%$, which was higher than the maximum extracted pectin of $21.7 \%$ from banana peels that used other extraction conditions $\left(90^{\circ} \mathrm{C}, 4 \mathrm{hrs}, \mathrm{pH} 1.5\right)$ reported by Happi Emaga, Ronkart, Robert et al. (2008). Phaiphan (2019) had revealed that the pectin yield extracted from banana peels using MAE conditions (580 W, 15.8 mins, $\mathrm{pH} 1.7$ ) was $13.57 \%$. Nevertheless, the extraction used by those authors was harsher than the extraction conditions of the present study. 
Table 1. Extraction yield of pectin, degree of esterification, methoxyl content, and galacturonic content from banana peels by using MAE

\begin{tabular}{|c|c|c|c|}
\hline \multirow{2}{*}{$\begin{array}{l}\text { Extraction } \\
\text { time (min) }\end{array}$} & \multicolumn{3}{|c|}{ Microwave power (Watt, W) } \\
\hline & 100 & 200 & 300 \\
\hline \multicolumn{4}{|c|}{ Yield of pectin (\%) } \\
\hline 5 mins & $2.03 \pm 0.23^{\mathrm{Bb}}$ & $2.47 \pm 0.44^{\mathrm{Cb}}$ & $20.93 \pm 0.73^{\mathrm{Aa}}$ \\
\hline 10 mins & $2.74 \pm 0.64^{\mathrm{Bb}}$ & $4.75 \pm 1.36^{\mathrm{Bb}}$ & $22.91 \pm 4.06^{\mathrm{Aa}}$ \\
\hline 15 mins & $7.54 \pm 2.15^{\mathrm{Ac}}$ & $14.75 \pm 0.94^{\mathrm{Ab}}$ & $22.65 \pm 2.74^{\mathrm{Aa}}$ \\
\hline \multicolumn{4}{|c|}{ Degree of esterification (\%) } \\
\hline 5 mins & $55.74 \pm 1.31^{\mathrm{Bb}}$ & $62.68 \pm 0.88^{\mathrm{Ba}}$ & $62.42 \pm 2.10^{\mathrm{Ba}}$ \\
\hline 10 mins & $51.85 \pm 3.20^{\mathrm{Bb}}$ & $62.42 \pm 2.10^{\mathrm{Ba}}$ & $66.66 \pm 0.00^{\mathrm{Ba}}$ \\
\hline 15 mins & $66.66 \pm 0.00^{\mathrm{Ab}}$ & $76.67 \pm 2.89^{\mathrm{Aa}}$ & $73.54 \pm 3.67^{\mathrm{Aa}}$ \\
\hline \multicolumn{4}{|c|}{ Methoxyl content $(\%)$} \\
\hline 5 mins & $9.09 \pm 0.22^{\mathrm{Bb}}$ & $10.20 \pm 0.14^{\mathrm{Ba}}$ & $10.15 \pm 0.34^{\mathrm{Ba}}$ \\
\hline 10 mins & $8.46 \pm 0.53^{\mathrm{Bb}}$ & $10.15 \pm 0.34^{\mathrm{Ba}}$ & $10.84 \pm 0.00^{\mathrm{Ba}}$ \\
\hline 15 mins & $10.84 \pm 0.00^{\mathrm{Ab}}$ & $12.51 \pm 0.47^{\mathrm{Aa}}$ & $12.00 \pm 0.60^{\mathrm{Aa}}$ \\
\hline
\end{tabular}

Galacturonic content (mg/g dry weight)

5 mins $\quad 130.39 \pm 2.49^{\mathrm{Ba}} \quad 156.52 \pm 6.60^{\mathrm{Aa}} \quad 150.14 \pm 22.75^{\mathrm{Ba}}$

10 mins $\quad 160.43 \pm 2.69^{\mathrm{Aa}} \quad 129.16 \pm 10.52^{\mathrm{Bb}} \quad 165.99 \pm 8.17^{\mathrm{Ba}}$

15 mins $\quad 130.19 \pm 5.89^{\mathrm{Bb}} \quad 103.03 \pm 5.66^{\mathrm{Cb}} \quad 238.21 \pm 52.13^{\mathrm{Aa}}$

Values are expressed as mean \pm standard deviation $(n=3)$. Values with different superscript letters in the row are significantly different at $p<0.05$ by Tukey's test.

The degree of esterification (DE), methoxyl content, and galacturonic content (GalA) of extracted pectin are presented in Table 1. The DE and methoxyl values of extracted pectin increased with the increase of microwave power and duration time. In the microwave power of $200 \mathrm{~W}$ and the extraction time of $15 \mathrm{mins}$, the $\mathrm{DE}$ and the methoxyl values were the highest, $76.67 \%$ and $12.51 \%$, respectively. This extraction condition was insignificant to the extraction of $300 \mathrm{~W}$ for 15 mins (DE $=73.54 \%$ and methoxyl content $=12 \%$ ).

Pectin is classified as a slow set (DE 58-65\%) and rapid set (DE $>72 \%$ ) which describes the rate of gel formation (Shaha et al., 2013). Therefore, pectin from banana peels of this study using microwave power of 200 and $300 \mathrm{~W}$ for 15 mins can be classified as rapid set pectin while that from microwave power of 200 and 300 $\mathrm{W}$ (at 5 and $10 \mathrm{mins}$ ) and $100 \mathrm{~W}$ (15 mins) are slow set pectin. Most of the methoxyl content of commercial pectins vary from 8 to $12 \%$ (to form high sugar gels), the extracted pectin has a higher methoxyl content since it will be able to disperse in water with anything less than 7\% (Rouse et al., 1962). In this study, the methoxyl content is in the range that can form a high sugar gel ( $>65 \%$ of sugar).

The GalA values of extracted pectin with changes in operating conditions ranged from 103.03 to $238.21 \mathrm{mg} / \mathrm{g}$ $\mathrm{dw}$ (Table 1). The GalA was enhanced by increasing microwave powers and extraction times. The microwave power of $300 \mathrm{~W}$ and the extraction time of $15 \mathrm{mins}$ had the highest GalA at $238.21 \mathrm{mg} / \mathrm{g}$ dw. (or $57.27 \%$ ), it was even higher than what was reported by Happi Emaga, Ronkart, Robert et al. (2008), which had a GalA content of $40 \%$ and a DE content of $49 \%$. The improvement of solvent permeation into the sample tissues during the titration method of the sample can enhance the GalA content (Kratchanova et al., 2004). Thus, results showed that the optimum conditions of pectin extraction by MAE to get a high yield and a maximum DE, methoxyl content, and GalA content were: $300 \mathrm{~W}$ of microwave power for 15 mins.

\subsection{Pectin extraction by using $U A E$}

\subsubsection{Effect of temperature and sonication time on yield and chemical characteristics of pectin}

The results show that the interactive effects of temperature and time significantly $(p<0.05)$ affected all the responses, the data are presented in Table 2. The yield values increased with the increase of sonication time (5-15 mins) and at $40^{\circ} \mathrm{C}$ and it declined afterwards at $50^{\circ} \mathrm{C}$. The pectin yield declined at $50^{\circ} \mathrm{C}$ because it had reached the highest maximum temperature that can affect the degradation of pectin (Zhang et al., 2013). The pectin yields ranged from 1.81 to $3.49 \%$. The temperature of $40^{\circ} \mathrm{C}$ and sonication time of 15 mins had the highest yield at $3.49 \%$. The pectin yield can be improved by ultrasound since the ultrasound produces the cavitation bubbles that cause plant cell wall disruption (Bhaskaracharya et al., 2009). The shear stress is increased by breaking of these bubbles, which results in the degradation of pectin structure into smaller substances (Patist et al., 2008). This result is similar to the report by Pagán et al. (2001) who noted that higher sonication time significantly $(p<0.05)$ increased the extraction yield.

The DE, methoxyl content and GalA content of extracted pectin are presented in Table 2. At a temperature of $30^{\circ} \mathrm{C}$ and sonication time of $10 \mathrm{~min}$, the highest DE and methoxyl content values were seen with percentages of $89.65 \%$ and $14.63 \%$ respectively and this extraction condition had no significant difference to extraction at $50^{\circ} \mathrm{C}$ for $10 \mathrm{mins}(\mathrm{DE}=88.42 \%$ and methoxyl content $=14.43 \%$ ). Since the $\mathrm{DE}$ values of this study are higher than $50 \%$, then it can be classified as a high methoxyl pectin (HMP) group. HMP is a rapid set pectin, it will be able to dissolve in water to form a high concentration of sugar gel ( $>65 \%$ of sugar) with a low pH (2.0-3.5) (Yapo et al., 2007).

The GalA content ranged from 200.78 to $476.60 \mathrm{mg} /$ $\mathrm{g} \mathrm{dw}$, the temperature of $50^{\circ} \mathrm{C}$ and sonication time of 10 min had the highest GalA at $476.60 \mathrm{mg} / \mathrm{g} \mathrm{dw}$ (or 
95.32\%) as shown in Table 2. From the extraction method, the ester bond in pectin was hydrolysed and it released more free carboxyl groups instead of increasing GalA content which is high in galacturonan chain (Ogutu and $\mathrm{Mu}, 2016)$. The GalA content of this study was higher than what was reported by Happi Emaga et al. (2008), which had a GalA and DE content of $40 \%$ and $49 \%$ respectively, from extracted banana peels. Based on the results above, it can be concluded that the optimum conditions of pectin extraction by UAE to get a maximum of DE, methoxyl and GalA content were at a temperature of $50^{\circ} \mathrm{C}$ for 10 mins.

Table 2. Extraction yield of pectin, degree of esterification, methoxyl content, and galacturonic content from banana peels by using UAE

\begin{tabular}{cccc}
\hline \multirow{2}{*}{$\begin{array}{c}\text { Extraction } \\
\text { time }(\text { min })\end{array}$} & 30 & 40 \\
\hline Yield of pectin $(\%)$ & 50 \\
\hline 5 mins & $1.81 \pm 0.15^{\mathrm{Bc}}$ & $2.91 \pm 0.07^{\mathrm{Ba}}$ & $2.33 \pm 0.26^{\mathrm{Ab}}$ \\
10 mins & $2.13 \pm 0.10^{\mathrm{Bb}}$ & $3.31 \pm 0.25^{\mathrm{Aa}}$ & $2.28 \pm 0.14^{\mathrm{Ab}}$ \\
15 mins & $3.15 \pm 0.44^{\mathrm{Aa}}$ & $3.49 \pm 0.19^{\mathrm{Aa}}$ & $2.36 \pm 0.20^{\mathrm{Ab}}$ \\
\hline Degree of esterification $(\%)$ & \\
\hline 5 mins & $89.27 \pm 0.47^{\mathrm{Aa}}$ & $81.75 \pm 1.86^{\mathrm{Ab}}$ & $88.39 \pm 4.88^{\mathrm{Aa}}$ \\
10 mins & $89.65 \pm 2.51^{\mathrm{Aa}}$ & $80.13 \pm 2.28^{\mathrm{Ab}}$ & $88.42 \pm 3.16^{\mathrm{Aa}}$ \\
15 mins & $83.45 \pm 2.54^{\mathrm{Ba}}$ & $81.71 \pm 1.75^{\mathrm{Aa}}$ & $83.84 \pm 1.31^{\mathrm{Aa}}$ \\
\hline Methoxyl content $(\%)$ & & \\
\hline 5 mins & $14.57 \pm 0.08^{\mathrm{Aa}}$ & $13.34 \pm 0.30^{\mathrm{Ab}}$ & $14.43 \pm 0.80^{\mathrm{Aa}}$ \\
10 mins & $14.63 \pm 0.41^{\mathrm{Aa}}$ & $13.08 \pm 0.37^{\mathrm{Ab}}$ & $14.43 \pm 0.52^{\mathrm{Aa}}$ \\
15 mins & $13.62 \pm 0.41^{\mathrm{Ba}}$ & $13.34 \pm 0.29^{\mathrm{Aa}}$ & $13.68 \pm 0.21^{\mathrm{Aa}}$ \\
\hline Galacturonic content $(\mathrm{mg} / \mathrm{g}$ dry weight $)$ & \\
\hline 5 mins & $200.78 \pm 27.75^{\mathrm{Bc}}$ & $260.25 \pm 27.08^{\mathrm{Bb}}$ & $350.99 \pm 33.33^{\mathrm{Ba}}$ \\
10 mins & $295.43 \pm 34.57^{\mathrm{Ab}}$ & $289.26 \pm 74.70^{\mathrm{Bb}}$ & $476.60 \pm 26.23^{\mathrm{Aa}}$ \\
15 mins & $263.64 \pm 12.65^{\mathrm{Ab}}$ & $382.47 \pm 3.09^{\mathrm{Aa}}$ & $381.85 \pm 1.23^{\mathrm{Ba}}$ \\
\hline
\end{tabular}

Values are expressed as mean \pm standard deviation $(n=3)$. Values with different superscript letters in the row are significantly different at $p<0.05$ by Tukey's test.
3.3 Yield and physico-chemical characteristics of extracted pectin from banana peel by MAE and UAE compared to commercial citrus pectin

The physico-chemical characteristics of pectin extracts are shown in Table 3. Colour $\left(L^{*} a^{*} b^{*}\right)$ parameters of the pectin under the optimum conditions of MAE, UAE, and commercial citrus pectin had a significant difference $(p<0.05)$. The pectin extracted under the optimum UAE conditions showed higher levels of lightness and yellowness than MAE but all colour parameters of commercial citrus pectin were still greater than both of them.

The moisture content of pectin under UAE (8.0\%) was not significantly different from the commercial citrus pectin $(7.31 \%)$. The extracted pectin should have a lower moisture content for longer storage time and inhibition of microorganism growth that can be produced pectinase enzymes (Muhmad-Zadeh et al., 2010). For ash content, commercial citrus pectin has a low ash content of $1.84 \%$ while the pectin from UAE had lower ash content $(3.39 \%)$ than the pectin from MAE (5.40\%), whereby lower ash content implies that pectin has a better quality of gel formation (Norazelina et al., 2011).

The extracted pectin by UAE had a degree of esterification (DE) of $88.83 \%$, it was higher compared with the pectin under MAE $(75.50 \%)$ while commercial citrus pectin has DE of $78.92 \%$, which were significantly different $(p<0.05)$. Then, pectin under MAE and UAE of this study and commercial citrus pectin could be classified as a rapid set (DE $>72 \%$ ) (Shaha et al., 2013), which describes the rate of gel formation.

Most of the methoxyl content of commercial pectins vary from 8 to $12 \%$ (to form high sugar gels) (Rouse $e t$ al., 1962). The extracted pectin by UAE obtained methoxyl content of $14.50 \%$ and it was higher compared

Table 3. Yield and physico-chemical characteristics of extracted pectin from banana peels by MAE and UAE compared to commercial citrus pectin.

\begin{tabular}{cccc}
\hline \multirow{2}{*}{ Characteristics } & Pectin extracted by MAE & Pectin extracted by UAE & Commercial citrus pectin \\
\cline { 2 - 4 } & $(300 \mathrm{~W}, 15 \mathrm{mins})$ & $\left(50^{\circ} \mathrm{C}, 10 \mathrm{mins}\right)$ & - \\
\hline Yield of pectin (\%) & $22.65 \pm 2.19^{\mathrm{a}}$ & $2.32 \pm 0.13^{\mathrm{b}}$ & $79.63 \pm 0.03^{\mathrm{a}}$ \\
$\mathrm{L}^{*}$ & $43.81 \pm 0.10^{\mathrm{c}}$ & $54.02 \pm 0.01^{\mathrm{b}}$ & $3.55 \pm 0.02^{\mathrm{b}}$ \\
$\mathrm{a}^{*}$ & $3.05 \pm 0.10^{\mathrm{c}}$ & $11.11 \pm 0.03^{\mathrm{a}}$ & $15.51 \pm 0.03^{\mathrm{b}}$ \\
$\mathrm{b}^{*}$ & $4.27 \pm 0.14^{\mathrm{c}}$ & $17.67 \pm 0.01^{\mathrm{a}}$ & $7.31 \pm 0.73^{\mathrm{b}}$ \\
Moisture content (\%) & $8.98 \pm 0.40^{\mathrm{a}}$ & $8.00 \pm 0.215^{\mathrm{b}}$ & $1.84 \pm 0.05^{\mathrm{c}}$ \\
Ash content (\%) & $5.40 \pm 1.19^{\mathrm{a}}$ & $3.39 \pm 0.14^{\mathrm{b}}$ & $78.92 \pm 2.16^{\mathrm{b}}$ \\
Degree of esterification (\%) & $75.50 \pm 2.36^{\mathrm{c}}$ & $88.83 \pm 2.46^{\mathrm{a}}$ & $12.88 \pm 0.35^{\mathrm{b}}$ \\
Methoxyl (\%) & $12.00 \pm 0.30^{\mathrm{b}}$ & $14.50 \pm 0.40^{\mathrm{a}}$ & $98.5 \pm 0.50^{\mathrm{a}}$ \\
\hline
\end{tabular}

Values are expressed as mean \pm standard deviation $(n=3)$. Values with different superscript letters in the row are significantly different at $\mathrm{p}<0.05$ by Tukey's test. 
with the pectin under $\operatorname{MAE}(12.0 \%)$, while the pectin extracted by MAE was not significantly different when compared with the commercial citrus pectin (12.88\%). The extracted pectin has a higher methoxyl content and it could be dispersed in water with less than 7\% (Rouse et al., 1962). Thus, in this study, the methoxyl content is in the range (8-12\%) that can form a high sugar gel $(>65 \%$ of sugar).

The galacturonic acid or GalA content of pectin revealed the purity and the physical properties of pectin, whereby pectin has higher GalA content and lower ash content and can be defined as a good purity level of pectin (Ranganna, 1986; Hwang et al., 1992). The GalA content obtained from pectin extracted under the UAE of $90.07 \%$, was higher compared with the pectin under the MAE $(57.80 \%)$. The GalA content of extracted pectin from UAE is comparable with the commercial citrus pectin (98.5\%). Even though, the pectin yield of MAE is high it has a low purity level of pectin when compared to the UAE method. Based on the results above, in terms of parameters such as moisture, ash, DE, methoxyl, and GalA content of pectin; the optimum conditions of UAE is more comparable with commercial citrus pectin than the pectin extracted under MAE.

\section{Conclusion}

Pectin was successfully extracted from banana peels under different conditions. The varied extraction conditions were studied for pectin extraction by using microwave and ultrasound-assistant extraction. The results revealed that the highest yield, DE, methoxyl and GalA content for MAE were microwave power of $300 \mathrm{~W}$ for $15 \mathrm{~min}$, and for $\mathrm{UAE}$ were $50^{\circ} \mathrm{C}$ for $10 \mathrm{mins}$. However, in terms of parameters, the yield and chemical characteristics of extracted pectin from banana peels by using UAE are more comparable to commercial citrus pectin than the pectin extracted under MAE. Moreover, further purification step of extracted pectin by UAE is needed to be optimised in order to acquire a higher quality of pectin.

\section{Conflict of interest}

The authors declare no conflict of interest.

\section{Acknowledgements}

The authors are grateful to RDI (Research and Development Institute, Ubon Ratchathani Rajabhat University) for the financial support (Grant No. 621001) and to the Faculty of Agriculture, Ubon Ratchathani Rajabhat University for providing the necessary facilities.

\section{References}

AOAC. (2000). Official Method of Analysis of AOAC International, 18th ed. Washington DC, USA: AOAC.

Bhaskaracharya, R.K., Kentish, S. and Ashokkumar, M. (2009). Selected applications of ultrasonics in food processing. Journal of Food Engineering Review, 1 (1), 31-49. https://doi.org/10.1007/ s12393-009-9003 $-7$

Bochek, A.M., Zabivalova, N.M. and Petropavlovskii, G.A. (2001). Determination of the esterification degree of polygalacturonic acid. Russian Journal of Applied Chemistry, 74(5), 796-799. https:// doi.org/10.1023/A:1012701219447

Castillo-Israel, K.A.T., Baguio, S.F., Diasanta, M.D.B., Lizardo, R.C.M., Dizon, E.I. and Mejico, M.I.F. (2015). Extraction and characterization of pectin from Saba banana [Musa 'saba' (Musa acuminate $\mathrm{x}$ Musa balbisiana)] peel wastes: A preliminary study. International Food Research Journal, 22(1), 202207.

Dedduang, O. (2010). Comparison of extracted pectin from three kinds of guava (Psidium guajava L.) to standard pectin. Bangkok: Srinakharinwirot University, MSc thesis.

FAO. (2019). Food loss and Food waste. Retrieved on September 27, 2019 from FAO website: http:// www.fao.org/food-loss-and-food-waste/en/.

FAOSTAT. (2018). Banana production in 2018, Crops/ Regions/World list/Production Quantity (pick lists). Food and Agriculture Organization, Corporate Statistical Database (FAOSTAT). Retrieved on September 27, 2019 from FAOSTAT Website: http://www.fao.org/fileadmin/templates/est/COMM MARKETS_MONITORING/Bananas/Documents/ Banana_Market_Review_Prelim_Results_2018.pdf Happi Emaga, T., Robert, C., Ronkart, S.N., Wathelet, B. and Paquot, M. (2008). Dietary fibre components and pectin chemical features of peels during ripening in banana and plantain varieties. Bioresource Technology, 99(10), 4346-4354. https:// doi.org/10.1016/j.biortech. 2007.08.030

Happi Emaga, T., Ronkart, S.N., Robert, C., Wathelet, B. and Paquot, M. (2008). Characterisation of pectins extracted from banana peels (Musa AAA) under different conditions using an experimental design. Food Chemistry, 108(2), 463-471. https:// doi.org/10.1016/j.foodchem. 2007.10.078

Hwang, J., Roshdy, T.H., Kontominas, M. and Kokini, J.L. (1992). Comparison of dialysis and metal precipitation effects on apple pectin. Journal of Food Science, 57(5), 1180-1184. https://doi.org/ 10.1111/ j.1365-2621.1992.tb11293.x

Khamsucharit, P., Laohaphatanalert, K., Gavinlertvatana, 
P., Sriroth, K. and Sangseethong, K. (2018). Characterization of pectin extracted from banana peels of different varieties. Food Science and Biotechnology, 27(3), 623-629. https:// doi.org/10.1007/s10068-017-0302-0

Kratchanova, M., Pavlova, E. and Panchev, I. (2004). The effect of microwave heating of fresh orange peels on the fruit tissue and quality of extracted pectin. Carbohydrate Polymers, 56(2), 181-185. https://doi.org/10.1016/j.carbpol.2004.01.009

Li, D., Jia, X., Wei, Z. and Liu, Z.Y. (2012). BoxBehnken experimental design for investigation of microwave-assisted extracted sugar beet pulp pectin. Carbohydrate Polymers, 88(1), 342-346. https:// doi.org/10.1016/j.carbpol.2011.12.017

Lucia, C.V., Reinaldo, F.T. and Carmen, L.O.P. (2013). Extraction and characterization of pectin from Cacao Pod Husks (Theobroma cacao L.) with citric acid. Journal of Food Science Technology, 49(1), 108116. https://doi.org/10.1016/j.lwt.2012.04.018

Minkov, S., Minchev, A. and Paev, K. (1996). Modelling of the hydrolysis and extraction of apple pectin. Journal of Food Engineering, 29(1), 107-113. https://doi.org/10.1016/0260-8774(95)00039-9

Muhmad-zadeh, J., Sadeghi-Mahoonak, A.R., Yaghbani, M. and Aalami, M. (2010). Extraction of pectin from sunflower head residues of selected Iranian cultivars. World Applied Sciences Journal, 8(1), 21-24.

Norazelina, S.M. and Nazarrudin, R. (2011). Extraction and characterization of pectin from dragon fruit (Hylocereus polyrrhizus) using various extraction conditions. Sains Malaysiana, 41(1), 41-45.

Ogutu, F.O. and Mu, T.H. (2017). Ultrasonic degradation of sweet potato pectin and its antioxidant activity. Ultasonics Sonochemistry, 38, 726-734. https:// doi.org/10.1016/j.ultsonch.2016.08. .014

Oliveira, T.S., Rosa, M.F., Cavalcante, F.L., Pereira, P.H.F., Moates, G.K., Wellner, N., Mazzetto, S.E., Waldron, K.W., Henriette, M. and Azeredo, C. (2016). Optimization of pectin extraction from banana peels with citric acid by using response surface methodology. Food Chemistry, 198(1), 113$118 . \quad$ https://doi.org/10.1016/j.foodchem. 2015.08.080

Pagán, J., Ibarz, A., Llorca, M., Pagán, A. and BarbosaCánovas, G.V. (2001). Extraction and characterization of pectin from stored peach pomace. Food Research International, 34(7), 605-612. https://doi.org/10.1016/S0963-9969(01)00078-3

Patist, A. and Bates, D. (2008). Ultrasonic innovations in the food industry: from the laboratory to commercial production. Journal of Innovative Food Science and Emerging Technologies, 9(2), 147-154. https:// doi.org/10.1016/j.ifset.2007.07.004
Phaiphan, A. (2019). Optimisation of pectin extraction assisted by microwave from banana (Musa sapientum L.) fruit peels using response surface methodology. Carpathian Journal of Food Science and Technology, 11(2), 127-140. https:// doi.org/10.34302/crpjfst/2019.11.2.10

Qiu, L., Zhao, G., Wu, H., Jiang, L., Li, X. and Liu, J. (2010). Investigation of combined effects of independent variables on extraction of pectin from banana peel using response surface methodology. Carbohydrate Polymers, 80(2), 326-331. https:// doi.org/10.1016/j.carbpol. 2010.01.018

Ranganna, S. (1986). Handbook of analysis and quality control for fruit and vegetable products. New Delhi, India: Tata Mc Graw-Hill Publishing Company.

Rolin, C. (1993). Pectins. In Whistler, R.L. and BeMiller, J.N. (Eds.), Industrial gums: Polysaccharides and their derivatives. $3^{\text {rd }}$ ed. p.257293. San Diego, USA: Academic Press. https:// doi.org/10.1016/B978-0-08-092654-4.50014-0

Rouse, A.H., Atkins, C.D. and Moore, E.L. (1962). The occurrence and evaluation of pectin in component parts of Valencia oranges during maturation. Proceedings of the Florida State Horticultural Society, 75, 307-311.

Shaha, R.K., Nayagi, Y., Punichelvana, A. and Afandi, A. (2013). Optimized extraction condition and characterization of pectin from Kaffir lime (Citrus hystrix). Research Journal of Agriculture and Forestry Sciences, 1(2), 1-11.

Tangwongchai, R., Lerkchaiyaphum, K., Nantachai, K. and Rojanakorn, T. (2006). Pectin extraction from Citron peel (Citrus medica Linn.) and its use in food system. Songklanakarin Journal of Science and Technology, 28(6), 1351-1363.

Voragen, A.G.J., Pilnik, W., Thibault, J.F., Axelos, M.A.V. and Renard, M.G.C. (1995). Pectins. In A.M. Stephen (Ed.), Food polysaccharides and their applications, p. 288-310. New York, USA: Marcel Dekker Inc.

Yapo, B.M., Robert, C., Etienne, I., Wathelet, B. and Paquot, M. (2007). Effect of extraction conditions on the yield, purity and surface properties of sugar beet pulp pectin extracts. Food Chemistry, 100(4), 13561364.

https://doi.org/10.1016/ j.foodchem.2005.12.012

Zhang, L.F., Ye, X.Q., Ding, T., Sun, X.Y., Xu, Y.T. and Liu, D.H. (2013). Ultrasound effects on the degradation kinetics, structure and rheological properties of apple pectin. Ultrasonics Sonochemistry, 20(1), 222-231. https:// doi.org/10.1016/j.ultsonch.2012.07.021 